\title{
住民意識に基づく長野オリンピック施設の経済的価值 評価
}

\section{An Economic Evaluation of Nagano Olympic Institutions Based on Residents' Consciousness}

藤居良夫 ${ }^{*}$ 河田明博 ${ }^{*}$

Yoshio FUJII, Akihiro KAWATA

摘要：近年, 地方自治体や政府が行う公共事業に対し, 厳しい目が向けられ, その合理的な費用対効
果の検討が必要である。本研究では, 現在長野市が行っている長野オリンピック施設の維持管理に対
して住民意識による経济的価值評価を CVM で分析した。また, 回答者属性, 質問項目別による支払
意志額の違いの検討も行った。

結果として, 長野市全体の集計値は, 現在長野市が負担している維持管理費よりわずかながら上回

る値となり，今後の維持管理のあり方について検討した。

\section{1. 本研究の背景と目的}

近年，政府や地方自治体などが行う公共事業に対して，㛜しい 目が向けられている。長野県内においてもそのような光景は見ら れる。

1998 年 2 月, 長野県の各地域に打いて華やかで盛大な冬季才 リンピックが開催された。今も開催された地域には多くの施設が 残されている。長野市内には 6 施設が残されて掞り，その 6 施設 之は，集客型施設のビッグハット・エムウェーブ，市民サービス 型施設のホワイトリンク・南長野運動公園・アクアウィング, 中 間型施設のスパイラルである。

これらの施設の維持管理費が問題になっている。現在施設の維 持管理体制は, 長野市が財政から 8 割を負担している。長野市が 各施設に負担している維持管理費" は表一1の々抢りである。

この維持管理体制には賛否両論の意見がある。オリンピックが 開催された都市の遺産として維持管理するのは当然だという意見 ああれば，高額な負担金を負担してまであ維持管理する必要はな いという意見むある。そこで本研究では, 現在の長野市が行って いる維持管理に対して, 住民意識による経済的価值評価を分析す ることにより，今後の維持管理のあり方を検討した。

\section{表－1＼cjkstart長野オリンピック施設維持管理費長野市負担分} ( $\mathrm{H} 11$ 年度分)

\begin{tabular}{|c|c|}
\hline 施設名 & 維持管理費 $($ 円 $)$ \\
\hline ビッグハット & $129,666,257$ \\
\hline エムウェーブ & $132,554,908$ \\
\hline アクアウィング & $103,597,289$ \\
\hline 南長野運動公園 & $233,386,989$ \\
\hline ホワイトリンク & $128,097,369$ \\
\hline スパイラル & $126,149,162$ \\
\hline
\end{tabular}

\section{2. 研究の方法}

長野オリンピック施設のような非市場財を評価することは非常 に困難である。非市場財の経済的評価の推定方法はいくつかある が, ここでは, 近年研究の盛んな仮想評価法 (Contingent Valuation Method: CVM）による方法を用いた。

本研究で問題となった点は，6つの長野オリンピック施設をど のように評価するかである。CVM で各施設を 1 つずつ評価する
には, アンケート調查票を各施設ごとに作成し, それを回答者に 6 種類ずつ回答してもらう必要がある。しかし, それは回答者に かなりの精神的負担となり，また回収率の低下が䀣念されるため， 本研究では 6 施設をまとめて評価することにした。また, CVM で推定された支払意志額（WTP）が確かなものであるかどうか は確信しにくい。そこで本研究では, CVM で推定された支払意 志額の信頼性の検訳のために, モンテカルロ・シミュレーション による信頼区間の推定も行った。

\section{3. $\mathrm{CVM}^{2 \sim \sim 9}$ による評価}

\section{(1) CVM の概要}

CVM は，人々にアンケートを利用して非市場財が改善された， あるいは悪化した状態を説明し，それに対して支払意志額を聞き 出し，それを基に非市場財の貨幣価值を評価する方法である。特 徵としては，あらゆる対象に適用可能である。最近では，公共事 業の事前調査として，費用対効果を調査するために，公共施設な どに対して CVM が利用されるようになってきた。公共施設など の維持管理に関する既往の研究では, 近隣公園の維持管理に用す る費用を評価したもの 評価したもの ${ }^{6)}$ ，自然公園の環境維持を評価したもの られる。また，政策の費用便益に関する研究では，首都機能移転 に対する費用便益を分析したもの?，歴史的風土に対して経済的 評価を行ったもの ${ }^{81}$ などがある。これらの研究においては，住民 に身近な既存の公共施設などの整備之維持管理や，将来の政策に 関する費用便益を扱っている。本研究は，オリンピックという一 時のイベントに対して建設された既存の大規模公共施設であり, 住民の日常生活からは踈遠であるとも考えられるオリンピック施 設の維持管理問題を取り上げた。ここでは, CVM を用いて複数 のオリンピック施設の経済的価值評価を行い，回答者の支払意志 の割合と施設への訪問意志などから，施設の評価を試みた。

理論的には，あらゆる非市場財などを評価できる CVM である が，アンケートで評価を行うことから，バイアスの影響を受けや すい。バイアスとは，回答者に質問する内容や質問方法によって 評価が影響され，得られる評価額が真の值と異なったものになっ てしまうことである。ここでは，プレテストなどを行い，このバ イアスをできるだけ少なくするように心掛けた。

*信州大学工学部 **信州大学大学院工学系研究科 


\section{(2) アンケート調查}

CVMにおいて, アンケート調査票の設計が非常に重要である ことから，まずプレテストによって調査票のチェックを行い，不 備な点やわかりにくい点がないかどうかを確かめてから，必要な 修正を行い，本調査を実施した。

\begin{tabular}{|c|c|}
\multicolumn{1}{|c|}{ 表 -2 アンケート調査実施概要 } \\
\hline 調查対象地域 & 長野市 \\
\hline 調查期間 & $2000 / 11 / 1 \sim 11 / 30$ \\
\hline 調査方法 & 郵送法 \\
\hline サンプル抽出方法 & 多段抽出法 \\
\hline 配布数 & 1480 \\
\hline 回収数 & $588(39.7 \%)$ \\
\hline 有効回答数 & $525(35.4 \%)$ \\
\hline
\end{tabular}

本調査の実施概要は表一2 のとおりである。本研究では, 長野 市の財政から維持管理費がまかなわれていることを考慮して, 母 集団の対象範囲を長野市全世帯とした。サンプル抽出は, 多段抽 出法により，まず長野市の 35 地区別の世帯数比率にしたがって 配布数を分けて，地区ごとにアンケート調查票の配布数を決定し， その各地区でさらに無作為抽出を行った。サンプル抽出には, 電 話帳データベースソフト「黒船 2001」を利用した。調查票の配 布については世帯主宛てに送り, 回答に関しては世帯の家計がわ かる人にお願いするようにした。

調査票には, 長野オリンピック施設に関する概要, 写真, 地図 などを提示し, 回答者に情報を提供した。またアンケートでの質 問項目として,「長野オリンピック施設の維持管理」,「長野オリ ンピック施設の場所」,「長野オリンピック施設の訪問経験」,「今 後どの施設に訪れたいか」,「長野オリンピック施設は長野市のシ ンボルとしてふさわしいか」について尋ねた。また個人属性につ いて, 性別, 年齢, 世帯構成員数, 就学前または就学中の者の人 数, 職業, 出身地, 居住地区, 世帯年収について質問を行った。

\section{表 -3 掲示額の種類}

\begin{tabular}{|c|c|c|}
\hline $\begin{array}{c}\text { 初吅 } \\
\text { 提示類 }\end{array}$ & $\begin{array}{c}2 \text { 回目 } \\
\text { 提示額 } \\
\text { (Yes 回答時) }\end{array}$ & $\begin{array}{c}2 \text { 回目 } \\
\text { 提示額 } \\
\text { (No 回答壯) }\end{array}$ \\
\hline 300 & 500 & 100 \\
\hline 500 & 800 & 300 \\
\hline 800 & 1000 & 500 \\
\hline 1000 & 2000 & 800 \\
\hline 2000 & 3000 & 1000 \\
\hline 3000 & 4000 & 2000 \\
\hline 4000 & 5000 & 3000 \\
\hline 5000 & 7000 & 4000 \\
\hline 7000 & 10000 & 5000 \\
\hline 10000 & 15000 & 7000 \\
\hline
\end{tabular}

(単位: 円 /月額)

CVMにおいて, 支払意志額に関する質問は最も重要な部分と なる。まず, 長野オリンピック施設の維持管理費は長野市の財政 でまかなわれていることを考慮し, 支払方式は追加徽収による税 金方式を採用した。なお，回答者に追加的に税金を支払ってもら うことをあらかじめ記述しておいた。質問方式は, バイアスのこ とを考慮し, 信頼性が高いことで知られているダブルバウンド方 式を採用した。その際の提示額は表一 3 のと抢りである。質問文 中には, 月額負担金を最初に提示し, その後ろに年間負担金む提 示した。

仮想的な状況の説明と支払意志額に関する質問は図ー 1 のとお
今仮に，予算不足などのため長野市がオリンピック施設を維持管理できなく なり，長野市民の皆さんに費用を負担していただかない限り，現在のような 利用が出来なくなるとします。税金負担額として月額 1 世帯当り 5,000 円(年間 60,000円)を支払っていただければ今の状態は維持されるとします。このよう な場合，あなたは負担してもいいと思いますか。もし負担していたたくと，あな たの家計の一部が減ることとなります。

\section{図-1 支払意志額に関する質問例}

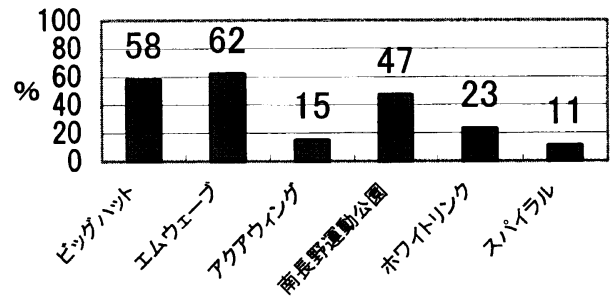

図ー 2 長野オリンピック施設の訪問経験（複数回答可）

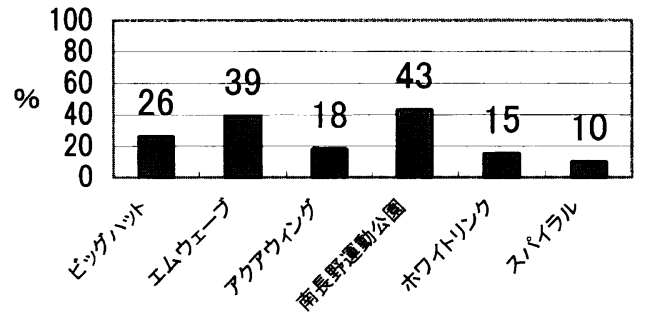

図ー３＼cjkstart長野オリンピック施設の訪問希望（複数回答可）

\begin{tabular}{|c|c|}
\hline ふさわしいと思う & ふさわしいと思わない \\
\hline Th+1 & 44 \\
\hline
\end{tabular}

図ー4＼cjkstart長野オリンピック施設が長野市のシンボルとしてふさわ しいか

りである。本研究では，2回と屯拒否回答をした回答者のみに， 拒否回答の理由を質問した。その項目として，「税金を払ってま で維持管理してほしくない」,「今後施設を使用しない」,「他の施 設を利用する」，「金額が高すぎる」，「その他」という選択肢を設 けた。

\section{4.アンケート回答結果}

以上のような調查票を用いて，本調査を実施した。回答者の属 性は表一 4 のとおりである。長野オリンピック施設の訪問経験と 訪問希望に関する回答結果は図- 2 㧍よび図ー 3 , また, 長野才 リンピック施設が長野市のシンボルとしてふさわしいかに対する 回答結果は四一 4 のとおりである。

表一 4 より, 調查票を世帯主宛てにしたため, 性別, 年齢に偏 りが見られる。また，子供（就学中または就学前の子供）の有無 では，いない方が多く，居住年数では， 9 割近くが 16 年以上長 野市に在住している。職業では, 会社員が最も多く, 世帯年収で は，400～599 万円，200〜399 万円が最も多い。図一2より，長 野オリンピック施設別の訪問経験に関しては, 集客型施設である ビッグハット，エムウェーブの訪問経験の割合が高い。しかし， 市民サービス型施設であるアクアウィング, 南長野運動公園, ホ ワイトリンクに関して, 訪問経験の割合は施設によって差がある。 また中間型施設であるスパイラルは，競技人口の少ないスポーッ 施設で，冬季のみ開設される施設であるため, 訪問経験の割合は 低いものとなっている。図ー3より, 長野オリンピック施設別の 訪問希望に関しては，全体的にはその割合は低く，とくに図-2 での訪問経験の割合の高かったビッグハット，エムウェーブに関 
表 -4 回答者の属性

\begin{tabular}{|c|c|c|c|c|c|c|c|c|c|c|}
\hline \multicolumn{2}{|c|}{ 性別 } & \multicolumn{8}{|c|}{ 世带年収 } & \\
\hline 男性 & 女性 & 200万円以下 & $200 \sim 399$ 万円 & $400 \sim 599$ 万円 & $600 \sim 799$ 万円 & $800 \sim 999$ 万円 & 1000〜1499万用 & 1500〜1999万网 & 2000 万円以上 & \\
\hline $440(83.8 \%)$ & $85(16.2 \%)$ & $30(5.7 \%)$ & $121(23.0 \%)$ & $124(23.6 \%)$ & $101(19.2 \%)$ & $67(12.8 \%)$ & $54(10.3 \%)$ & $13(2.5 \%)$ & $15(2.9 \%)$ & \\
\hline \multicolumn{2}{|c|}{ 子供の有無 } & \multicolumn{9}{|c|}{ 職業 } \\
\hline いる & いない & 農林業 & 会社員 & $\begin{array}{c}\text { 公務員 ·教職員 } \\
\text { 団体職員 } \\
\end{array}$ & 商工自営業 & $\begin{array}{c}\text { 弁護士・医師 } \\
\text { 会社役員 } \\
\end{array}$ & 専業主婦 & 無職 & 学生 & その他 \\
\hline $169(32.2 \%)$ & $356(67.8 \%)$ & $34(6.5 \%)$ & $150(28.6 \%)$ & $73(13.9 \%)$ & $56(10.7 \%)$ & $33(6.3 \%)$ & $29(5.5 \%)$ & $132(25.1 \%)$ & $3(0.5 \%)$ & $15(2.9 \%)$ \\
\hline \multicolumn{5}{|c|}{ 居住年数 } & \multicolumn{6}{|c|}{ 年齢 } \\
\hline $0 \sim 2$ 年 & $3 \sim 5$ 年 & $6 \sim 10$ 年 & $11 \sim 15$ 年 & 16 年以上 & 10 代 & 20 代 & 30代 & 40代 & 50代 & 60 代以上 \\
\hline $6(1.1 \%)$ & $16(3.0 \%)$ & $17(3.2 \%)$ & $20(3.8 \%)$ & $466(88.8 \%)$ & $2(0.3 \%)$ & $7(1.3 \%)$ & $29(5.5 \%)$ & $85(16.2 \%)$ & $133(25.3 \%)$ & $269(51.2 \%)$ \\
\hline
\end{tabular}

して, 訪問希望の割合が大きく下がっている。集客型施設として, もう少し集客に対する魅力度を上げる必要がある。また，市民サー ビス型施設の中で, 南長野運動公園は 2000 年 3 月より野球場之 してリニューアルしたこともあり, 訪問したいと考えている人が 他の施設より多い。図ー4より，長野オリンピック施設が長野市 のシンボルとしてふさわしいかに関しては，シンボルとしてふさ わしいと考える人の割合のほうがやや多い結果となった。

\section{5. 分析方法}

ダブルバウンド方式によって得られたデータから支払意志額を 推定する方法はいくつかあるが, 本研究では, 経済理論との整合 性が高いといわれているランダム効用関数モデルを採用した。

回答者が，長野オリンピック施設を維持管理していくため，提 示額を支払うことにYes と回答する確率は, 次式で表される。

$$
\operatorname{Pr}[\text { Yes }]=\frac{1}{1+e^{-\Delta V}}
$$

ここで，効用差 $\Delta V$ を次のように仮定する。

$$
\Delta V=\mathrm{a}_{0}-\mathrm{a}_{\bullet} \cdot \ln \mathrm{T}
$$

$a_{0}, a_{t}$ ：推定すべきパラメー夕

属性に関する変数として, 表一 5 に示す変数を用いて推定を行 つた。ここで,「年歯」,「居住年数」,「年収」に関しては選択肢 の中央值を用いた。また, 「職業」の有無については, 専業主婦, 無瞕, 学生を職業なしと定義した。

また本研究では, 支払意志額の信頼区間の計測も行った。モン テカルロ・シミュレーションを用いて，まず，各変数のパラメー 夕の推定值と漸近共分散行列を計算し，それらのデー夕を利用し て多変量正規分布に基づく乱数を発生させて，パラメー夕を 1000 組推定する。それに対応するWTP を 1000 個計算し，上下 50 個ずつ削除すると，90\%信頼区間が計測できる。

\section{6. 分析結果}

\section{(1) 全体推定}

上述の分析方法から得られた各変数のパラメー夕の推定值と WTP の結果はそれぞれ，表一6および表－7のようになった。

ただし，表一6では，有意な変数のみを表している。以上の結 果から，提示額のパラメー夕はマイナス符号となり，これは提示 額が低いほどY es と回答する確率が高いことを示している。ま た，その他のパラメータについては，プラス符号になっているこ とから, 年収が多く, 将来訪問したい施設数が多く, シンボルと してふさわしいと思っている回答者ほど Yes と回答する確率は 高いことが推测できる。

本研究では集計值を求めるにあたり, 支払意志額の質問におい て，2回とも拒否回答を示した回答者のうち，「税金を払ってま で維持管理してほしくない」,「今後施設を使用しない」,「他の施 設を利用する」，「その他」と回答した者（67人）については， 抵抗回答とみなした。集計値の推定に対して, 中央値を用いるか 平均值を用いるかは議論の分かれるところであるが, 本研究では, 統計的な信頼性の高い中央値 WTPによって集計值を求めること

\begin{tabular}{|c|}
\hline 性別（男性 $=1$ ，女性 $=0$ ） \\
\hline 年踰（年代の中央值に対数を取ったもの） \\
\hline 世帯人数 (人) \\
\hline 子供の数（人） \\
\hline 職業（あり $=1 ， な し=0 ）$ \\
\hline 居住年数（居住年数の中央値に対数を取ったもの） \\
\hline 出身地 (長野市 $=1$ 長野市以外 $=0)$ \\
\hline 年収（年収の中央值に対数を取ったもの） \\
\hline 場所に関する知識（知っている $=1$, 知らない $=0$ ) \\
\hline 訪問の回数（回） \\
\hline 将来訪問したい施設の数 \\
\hline $\begin{array}{c}\text { 長野市のシンボルとしてのふさわしさ } \\
(\text { ふさわしい=1, ふさわしいとは思わない=0) }\end{array}$ \\
\hline
\end{tabular}

表 -5 属性に関する変数

\begin{tabular}{|c|c|c|}
\hline 変数 & 推定值 & $\mathrm{P}$ 值 \\
\hline 定数項 & 2.29266 & $0.023 *$ \\
\hline 提示額 & -1.17964 & $0.000 * *$ \\
\hline 年収 & 0.657491 & $0.000 * *$ \\
\hline $\begin{array}{l}\text { 訪問したい } \\
\text { 施設の数 }\end{array}$ & 0.282729 & $0.000 * *$ \\
\hline $\begin{array}{c}\text { シンボルとして } \\
\text { のふさわしさ }\end{array}$ & 1. 253584 & $0.000 * *$ \\
\hline $\mathrm{n}$ & \multicolumn{2}{|c|}{525} \\
\hline 対数尤度 & \multicolumn{2}{|c|}{-538.279} \\
\hline
\end{tabular}

表 -6 各変数のパラメータの推定值（有意な変数のみ）

表 -7 支払意志額推定結果

\begin{tabular}{|c|c|c|}
\hline & WTP & $90 \%$ 信頼区問 \\
\hline 中央值 & 632.34 & $543.86 \sim 732.07$ \\
\hline 平均值 & 3657.27 & $2200.37 \sim 10557.21$ \\
\hline
\end{tabular}

(単位: 円/月)

にした。この支払意志額に長野市の全世帯数 (130994 世帯), 有 効回答の中で金額に関するデー夕の得られた割合（87.2\%)，お よび 12 ヶ月を乗じ, 集計值を求めると, 長野市全体で 8 億 6676 万円となった。これは現在長野市が負担している維持管理費 8 億 5,345万円よりあわずかながら上回る結果となった。したがって, 長野市民に限定した経济的評価であっても，長野オリンピック施 設に対する価値は認められ, 経済的価值評価の観点から, 長野市 の長野オリンピック施設に対する維持管理の負担については妥当 であるといえよう。

\section{（2）質問項目別による推定}

次に，質問項目別による支払意志額の違いを検討した。ここで は，全体推定で有意となった変数について，つまり「今後どの施 設に訪れたいか（行きたい，行きたくない)」，「長野オリンピッ ク施設は長野市のシンボルとしてふさわしいか（ふさわしいと思 
う，ふさわしいとは思わない)」という項目に対する回答者別に 中央值 WTP を求めた。なお, 効用関数のパラメー夕の推定結果 については省略する。

(1)将来長野オリンピック施設へ訪問希望する 914.73 円/月

将来長野オリンピック施設へ訪問希望しない１96.70円/月

(2)長野市のシンボルとしてふさわしいと思う１207.63円/月

長野市のシンボルとしてふさわしいとは思わない2 60.00 円/月

これらの結果より, 将来長野オリンピック施設へ訪問希望する, 長野市のシンボルとしてふさわしいと思うと答えた回答者ほど支 払意志額が高いことがわかる。とくに, 長野市のシンボルとして ふさわしいと思うと答えた回答者の支払意志額は, 非常に高い値 となっている。これらのことから, 利用価值および存在価值や遺 産価値としての評価が高いと考えられる。

\section{（3）質問項目と支払意志との関連性}

上で求めた質問項目別評価をさらに検討するために，「今後ど の施設に訪れたいか」,「長野オリンピック施設は長野市のシンボ ルとしてふさわしいか」という質問に対する回答割合と，支払意 志の有無の割合との関連性について $\chi^{2}$ 検定を行った。その結果 は表一 8 , 表一 9 のとおりである。

\section{表 -8 施設別の将来訪問希望と支払意志との関連性}

\begin{tabular}{|c|c|}
\hline 施設名 & $\chi^{2}$ 值 \\
\hline ビッグハット & $8.747^{*}$ \\
\hline エムウエーフ & $21.713^{* *}$ \\
\hline アクアウィング & $10.005^{* *}$ \\
\hline 南長野運動公園 & $16.489^{\star *}$ \\
\hline ホワイトリンク & $22.581^{* *}$ \\
\hline スパイラル & 0.671 \\
\hline \multicolumn{2}{|c|}{ ** $1 \%$ 水潅で有意 * $5 \%$ 水準で有意 } \\
\hline
\end{tabular}

\section{表－9シンボルとしてのふさわしさと支払意志との関連性}

\begin{tabular}{|c|c|}
\hline & $\chi^{2}$ 値 \\
\hline $\begin{array}{c}\text { シンボルとしての } \\
\text { ふさわしさ }\end{array}$ & $58.127^{\star *}$ \\
\hline
\end{tabular}

「今後どの施設に訪れたいか」については，施設別のWTP を 求められない代わりに，支払意志の有無の割合と，施設別の訪問 意志から関連性を検証してみた。

表一 8 の結果より，将来施設に訪問したいと回答した者の多く は，スパイラルを除き支払意志を示していることから，スパイラ ルを除く施設では将来への利用価値が見出されている。また，表一 9 の結果より, シンボルとしてふさわしいと回答した者の多くは, 支払意志を示していることがわかる。

つまり，今後長野オリンピック施設の価值を高めようとすると き, 長野市のシンボルとなるような施設の運営および管理に努め, オリンピック施設に行きたいと思わせるような魅力度を高めるこ とが重要であると考えられる。

\section{7. まとめ}

本研究では, 現在, 長野市が行っている長野オリンピック施設 の維持管理に対して，住民意識による経済的価值評価を行い，今 後の維持管理のあり方を検討した。長野オリンピック施設の維持 管理については，現在長野市が負担している維持管理費より CVM で求められた経済的価值の方がわずかながら上回る結果と なり，費用便益の観点からは，長野市の長野オリンピック施設に 対する維持管理費負担の妥当性は認められる。しかし，将来的に は地域の資源となるような管理および活用が必要であり，また地 域のシンボルとしての広報活動などが重要である。

今後の課題として, 本研究では, 長野オリンピック施設の維持 管理費の大半が長野市の財政から負担されていることから，長野 市全世帯を対象に調查を行ったが，施設利用などの観点から他の 地域住民の価值評価む検討する必要があり，さらに広域的な受益 範囲を設定することが考えられる。また，6 施設すべてをまとめ て評価するのでなく，個々の施設に対する維持管理のあり方を検 討することが必要である。

また，CVM は単一の非市場財の政策を提示して価值を評価す る手法であるが，非市場財には多くの属性が含まれていることか ら，単属性の評価だけでなく多属性の評価をする必要性む考えら れる。近年，非市場財に関する政策に対して多数の代替案を提示 して, 属性別に価值を評価する方法が注目されてきている。今後 は，このような評価手法との比較も検討する必要がある。

\section{参考文献}

1) 長野市体育課 (2000)：平成 11 年度長 野オリンピック施設維持管理費決算額

2 ）栗山浩一（1998）：環境の価值と評価 手法：北海道大学図書刊行会

3 ）栗山浩一（2000）：㘡解 環境評価と 環境会計：日本評論社

4 ) 肥田野登 (1999)：環境之行政の経済 評価：勁草書房
5 ）太田・萇茂（2001）：CVMによる近 隣公園の経済的価值評価の研究：ラン ドスケープ研究 64(5), 679-684

6 ）大西・今・加賀屋（2001）：まちづく り資源に対する思いいれ価值の計測に 関する研究：土木計画学研究講演集 24,376

7 ）片山・城所 ・瀬田・大西 (1999)：CV $\mathrm{M}$ を用いた首都機能移転の定量的評
価に関する研究：都市計画論文集 34 , $73-78$

8 ）青山・中川・松中・大場（2000）：京 都市民の意識に基づく古都保存法の経 済評価：都市計画論文集 35, 169-174

9 ) 庄子康（2001）：トラベルコスト法と 仮想評価法による野外レクリエーショ ン価值の評価之その比較：ランドスケー プ研究 64(5)，685-690

Summary : Recently, public works of the government or local government has been reconsidered. We verified whether the costs which Nagano city pays to maintain Nagano Olympic Institutions would be appropriate. We measured the economic value of Nagano Olympic Institutions based on the consciousness of the citizens of Nagano city using CVM (Contingent Valuation Method). And we investigated the relation between residents' conciousness and WTP(willingness to pay). As a result, it was found that the economic value of Nagano Olympic Institutions turned out to be about 867 million yen per year, and residents' who wanted to go to the Nagano Olympic Institution, or residents' who answered that the Nagano Olympic Institution was suitable as a symbol of Nagano city, showed willingness to payment. 